\section{Nadtochii V., Nadtochiy A., Bugrim L.}

\title{
DEVELOPMENT OF AUTOMATIC CONTROL SYSTEM OF MOTION OF AN UNMANNED SURFACE SHIPS WITH A SAILING INSTALIATION
}

Об’єктом дослідження є безекіпажне надводне судно з вітрильною установкою. Однією з проблем при керуванні вітрильним судном за допомогою автоматичних систем є майже нескінченна кількість статичних та динамічних станів традиційних вітрил, які важко виявляти $і$ які важко прогнозувати. Крім того, відомою є здатність традиційних вітрил до закручування та зачеплення, а всі операції з вітрилами виконуються через оперування бігучим та стоячим такелажем, тобто опосередковано. Якщо враховувати необхідність постійного розгортання та прибирання звичайних вітрил, то побудова системи автоматичного керування ними очевидно буде вкрай складним завданням.

В роботі розглядається альтернатива традииійному вітрилу - жорстке вітрило-крило. Для безекіпажних надводних суден вітрило-крило пропонується виготовляти на основі симетричних аеродинамічних профілей. Таке вітрило-крило дозволить спростити таку процедуру, як прибирання вітрила, тобто забезпечення його бездї, а також спростити процедуру переходу вітрильного судна рухом правим або лівим галсами.

В ході дослідження представлено відносно прості алгоритми керування, які можливі при використанні симетричних аеродинамічних профілей для жорстких вітрил. Такі вітрила дозволять відносно легко реалізувати режими руху безекіпажного судна галсами, а також режим без дї вітрила. Також показано необхідність побудови системи, яка поєднує функиї керування кутом атаки крила-вітрила та керування курсом. При цьому система керування кутом атаки не залежить від системи керування курсом, а система керування курсом має враховувати режим вітрильної установки. Подолання же критичних точок переходу судна з одного галса на інший можливо при використанні додаткового рушійного пристрою. Керування вітрилом-крилом може бути здійснено за допомогою одного єдиного електроприводу, що повертає його відносно вітру на заданий кут атаки, чим забезпечує його рушійну силу.

ключові слова: безекіпажне надводне судно, керування курсом судна, керування кутом атаки вітрила, інтегрована система керування, автокермовий.

Received date: 18.06 .2019

Accepted date: 09.07.2019

Published date: 31.10.2019
Copyright (C) 2019, Nadtochii V., Nadtochiy A., Bugrim L. This is an open access article under the CC BY license (http://creativecommons.org/licenses/by/4.0)

\section{Introduction}

The creation of unmanned sea ships, or in other words, sea drones, is engaged in all the leading marine countries of the world [1,2]. First of all, this is due to the wide horizons of the application of such technical systems at relatively low operating costs. The development of Ukraine as a maritime state [3] provides for innovative activity, which is also associated with the creation of robotic marine equipment. The problem of creating marine robotics in Ukraine is addressed by the Admiral Makarov National University of Shipbuilding in the city of Mykolaiv [4, 5].

Spheres of application for unmanned surface ships (USS) can be security activities related to natural resources, water areas, facilities, monitoring of underwater/surface situations, search and rescue operations, etc. The main problem when creating USS, especially a small tonnage, is a low battery life. This drawback significantly limits the demand for such marine equipment from interested parties. This circumstance determines the relevance of research related to increasing the USS autonomy, in particular, sailing, the time spent in the sea is practically unlimited. Thus, the object of research is an unmanned surface ship with a sailing installation. And the aim of research is studying the control processes of an automatic sail of an unmanned ship, as well as the spatial motion of a ship with a sailing propulsion system.

\section{Methods of research}

As it is known, traditional sails are poorly integrated into marine unmanned technologies, and above all with autonomous surface ships. Rigid wings with aerodynamic profiles can be used as alternative sails [6, 7]. It should be noted that the problems of using sails of a rigid structure are given a lot of attention [8,9]. In automatic sailing installations, the most optimal solution is to use wings with symmetrical profiles $[10,11]$. The aerodynamic forces on the symmetrical aerodynamic profile are identical in modulus, but are mirror-oriented relative to the chord of the profile at the same angle of attack with different signs. At $\alpha=0^{\circ}\left(\alpha= \pm 180^{\circ}\right)$, the aerodynamic force consists 
only of the drag force, which can reach several percent of the maximum value.

The advantage of rigid sails with a symmetrical profile is excellent handling. With the help of a single electric drive, it is easy to control the angle of attack, and hence the vector of aerodynamic forces and, ultimately, propulsive (driving) force. The use of rigid sails with a symmetrical aerodynamic profile makes it possible to solve two main problems relatively easily.

1. To ensure the same sail operation modes when the ship is moving left and right tack and a simple transition from motion with a direct course to the motion of tacks and vice versa.

2. To ensure the practical inactivity of the sail when the angle of attack $\alpha \approx 0^{\circ}\left(\alpha \approx 180^{\circ}\right)$ to stop the ship or in stormy conditions. In other words, to carry out weather vane sails.

Fig. 1 is a block diagram of the algorithm of the automatic control system of a sailing installation with a rigid sail - wing based on a symmetrical aerodynamic profile.

The angle of attack $\alpha$ of the sailwing is maintained automatically in such a way as to constantly provide the maximum aerodynamic force $\alpha=f(F \rightarrow \max )$.

As shown in the diagram of Fig. 2, the input data is the course angle of the apparent wind $\beta$ and the given tack. The first parameter is measurable using a wind direction sensor. The system compares the actual incidence angles of the apparent wind with the ship's course relative to the wind. If $\beta$ coincides with the corresponding course, the system sets the required angle of attack $\alpha$. The given tack of the ship is also controlled, which is necessary for the motion of the sailing ships against the wind, and in some cases also in the wind. Obviously, the direction of the apparent wind $\beta$ depends on the change in the given course $\varphi$ of the ship. This makes it necessary to take into account the process of controlling the angle of attack of the sail in the ship heading control system.

Fig. 2 shows a functional diagram of a sailing installation in combination with a steering complex for an unmanned ship.

The signals $V_{A}$ and $\beta$ measured by block 1 are sent to the sail orientation calculator.

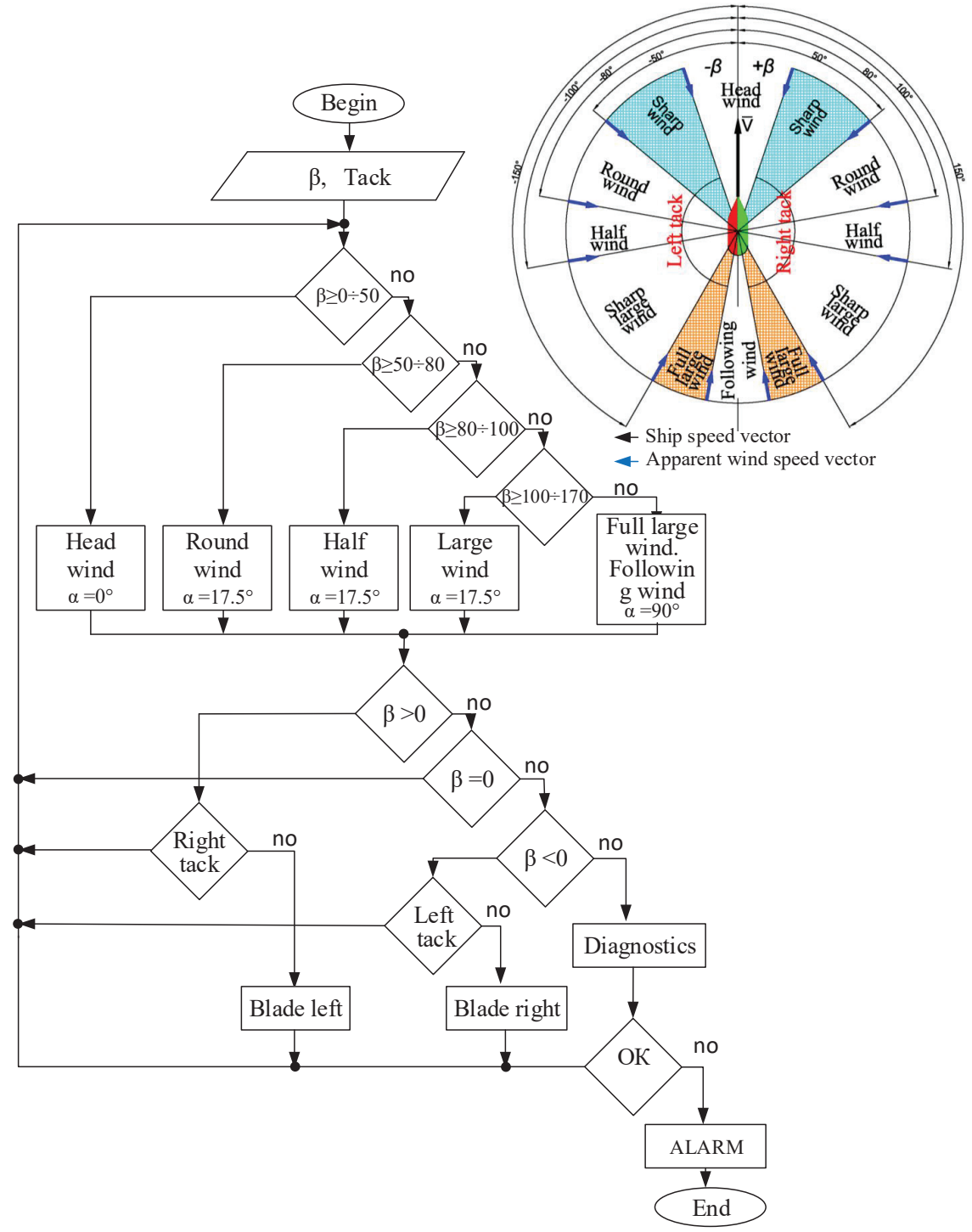

Fig. 1. The control algorithm of the angle of attack $\alpha$ of the sail-wing, depending on the angle of the apparent wind $\beta$ and tack

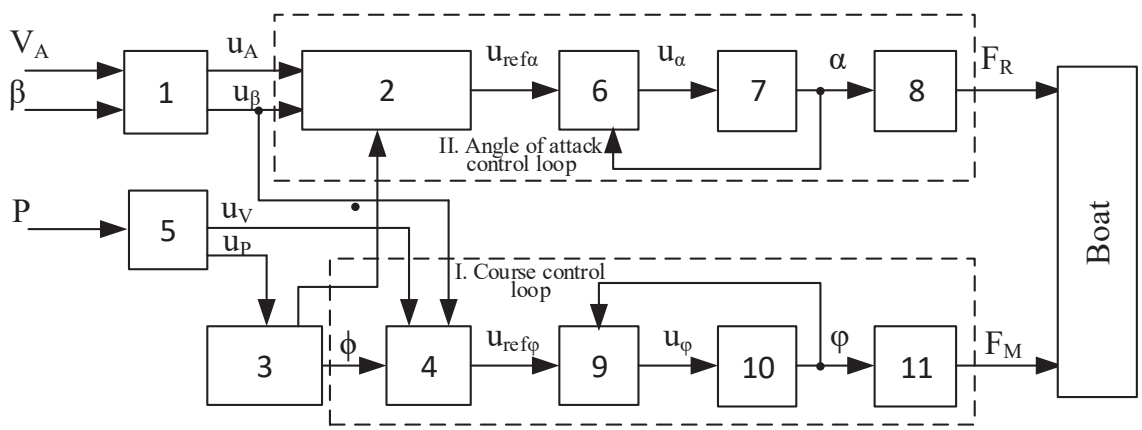

Fig. 2. The general functional diagram of the sailing installation of unmanned ship:

1 - measuring complex of speed and direction of the apparent wind; 2 - sail orientation calculator;

3 - course plotter; 4 - autocontrol; 5 - satellite navigation system (5NS); 6 - angle of attack regulator;

7 - electric sail rotation; 8 - sail; 9 - blade regulator; 10 - blade electric drive; 11 - blade; 12 - hull

If $\beta$ is within $\pm 0 \div 50^{\circ}$ with respect to the course of the ship (that is, the head wind course), then the sail angle control system gives the $u_{r e f \alpha}$ signal to set $\alpha=0$, that is, puts the sail in the wind vane mode. At the same time, the aerodynamic force and, accordingly, the driving force is 
absent, and the drag force of the sail is minimal and can be overcome if necessary with an electric propulsion system.

If $\beta$ is within $\pm 50 \div 80^{\circ}$ with respect to the heading of the ship (i. e., the round wind course), then the angle of attack control system generates the $u_{r e f \alpha}$ signal to establish $\alpha= \pm 17.5^{\circ}$ depending on the tack for maximum sail-wing efficiency (Fig. 1). Similarly, the process is repeated if $\beta$ is within $\pm 80 \div 150^{\circ}$ with respect to the course of the ship (i.e., the course is round wind, half wind, following wind).

If $\beta$ is within $\pm 150 \div 180^{\circ}$ with respect to the course of the ship (i. e., full large wind, following wind), then the angle of attack control system gives the $u_{\text {refa }}$ signal to establish $\alpha= \pm 90^{\circ}$ depending on the tack for maximum aerodynamic drag sail.

The angle of attack controller 6 , in accordance with the dynamic and static properties of the sail control channel, generates a signal for controlling the electric drive of the sail 7. The electric drive of the sail sets the angle of attack $\alpha$ at which an aerodynamic force of a certain direction with a moving component $F_{R}$ is created on the surface of the sail.

As noted above, automatic sail control is performed in conjunction with boat heading control. Therefore, the control device contains course plotter, in which all the coordinates of the route are entered and which has three modes of issuing tasks to the autocontrol:

1. Motion only with a sailing propulsive (propulsion) installation.

2. Motion only with an additional propulsive installation. As an additional engine, an internal (external combustion) engine or a propeller motor can be used.

3. Combined mode.

In the first course plotter mode, if necessary, generates the ship's trajectory in tacks in accordance with the given route and the measured direction of the apparent wind $\beta$.

In the second course plotter mode, it generates a trajectory of motion, coincides with a given route, and the sailing installation operates in a weather vane mode (for example, a head wind course or another).

In the third mode, the course plotter generates the ship's trajectory in tacks in accordance with a given route with the simultaneous operation of an additional propulsion system. In the framework of this work, the first mode is considered.

An autocontrol is designed to stabilize the boat at a given course and generates a $u_{r e f \varphi}$ reference signal for the blade regulator 9 , which with the necessary dynamic characteristics generates a control signal $u_{\varphi}$ of the blade electric drive 10 . The blade electric drive changes the position of the blade pen, which acts on the stern of the ship and returns it to the desired course.

The satellite navigation system transmits the vector $u_{P}$ of the ship's current coordinates (latitude $\varphi$ and longitude $\lambda$ ), as well as the ship speed $u_{V}$.

\section{Research results and discussion}

It is advisable to divide the task of controlling the motion of unmanned ships with a sailing propulsion system into two components (respectively, Fig. 2).

1. The task of the course plotter taking into account the requirements for a sailing installation.

2. The task of ensuring maximum efficiency of the sailing installation.

The first component is decided by the construction of specialized autocontrol device (ACD), which takes into account the specifics of the motion of the ship under the force of a sailing installation. In addition to the ACD traditional for automatic gearboxes, it is necessary to include a system for it that takes into account the ship's tack motion depending on the direction of the wind and the desired direction of motion. For small marine transport, it is advisable to use electric drives as steering machines. Therefore, the general system for controlling the course of an unmanned ship (Fig. 3) consists of the following components:

- M - memory;

- SD - setting device;

- GPS - Global Positioning and Navigation System;

- CC - course corrector;

- $\mathrm{CR}$ - course regulator;

- CS - speed control;

- AM - actuating mechanism;

- CB - control blade;

- BH - boat hull.

Memory $\mathrm{M}$ is designed to store the course change coordinates for the entire mission. These coordinates are recorded by the operator before the USS goes to sea.

The setting device $\mathrm{SD}$ is designed to determine the program heading angle $\varphi_{\mathrm{prg}}$, or the direction from the current coordinates of the ship, received from the satellite navigation system (SNS) to the following, recorded in memory M:

$$
\bar{V}=\left(a_{1}, a_{2}\right)_{\bar{V}}=\left(\lambda_{f}-\lambda_{c}\right)\left(\phi_{f}-\phi_{c}\right),
$$

where $\lambda_{f}, \lambda_{c}$ - longitude, respectively, of the given and current coordinates; $\phi_{f}, \phi_{c}-$ latitude of the given and current coordinates.

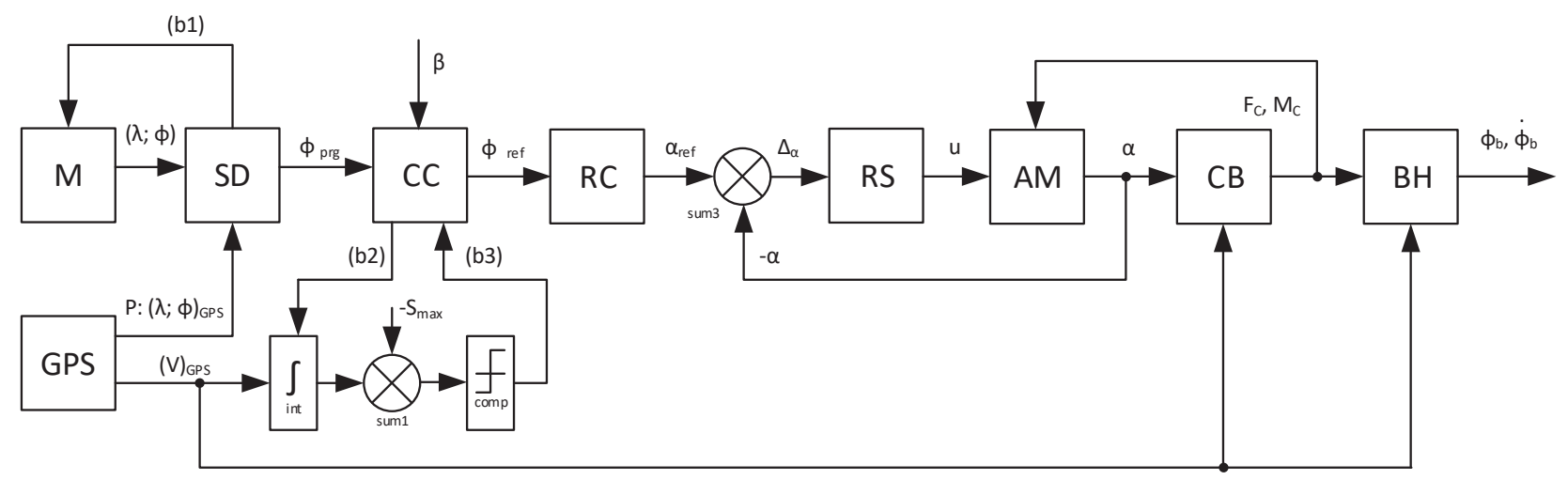

Fig. 3. General structure of the control system for the unmanned surface ship taking into account the operating mode of the sailing installation 
Where the program heading angle:

$$
\varphi_{p r g}=\cos ^{-1} \frac{\left(a_{1}\right)_{\bar{V}} \cdot\left(d_{1}\right)_{\bar{N}}+\left(a_{2}\right)_{\bar{V}} \cdot\left(d_{2}\right)_{\bar{N}}}{\sqrt{a_{1}^{2}+a_{2}^{2}} \cdot \sqrt{d_{1}^{2}+d_{2}^{2}}},
$$

where $\bar{V}$ - vector $\left(a_{1}, a_{2}\right)$ to the point of change of course; $\bar{N}$ - vector $\left(d_{1}, d_{2}\right)$ to the north; $\varphi_{p r g}$ - program heading angle.

In addition, the SD unit generates a request signal b1 of the next coordinate when it reaches the specified one. Fig. 4 shows the mechanism for forming a program heading angle for a programmed route through points $A B C D$. Based on the coordinates of the current point $A$ and the coordinates of the given point of change in the course $B$, a motion vector $\bar{V}$ is determined. Then, on the basis of $\bar{V}$ and the known direction to the magnetic north pole $\bar{N}$, expression (2) determines the necessary program heading angle $\varphi_{p r g}$.

Upon reaching point $B$, the $S D$ block issues a request $b 1$ to the memory for issuing the next predetermined point of change of course $C$, a new motion vector $\bar{V}$ and a new program heading angle are determined. Next, the process is repeated, and at the output of the $S D$ block over time, with successive passage of sections of a given route, the necessary directions of the USS motion are formed.

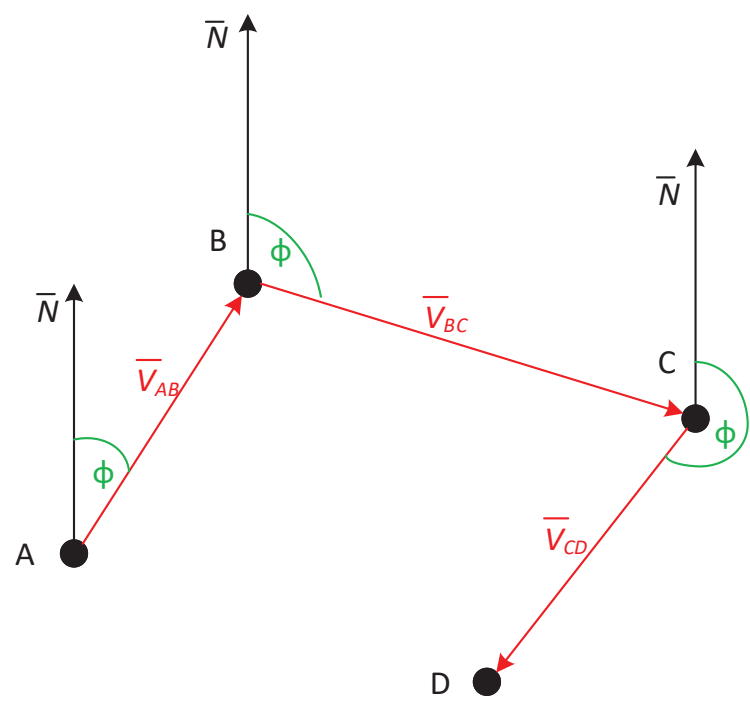

Fig. 4. The scheme for determining the program heading angle $\varphi_{p r g}$ at the points of a given route $A B C D$

The course corrector (CC) block forms, based on $\varphi_{\text {prg }}$, the signal of the given course $\varphi_{\text {ref }}$, which can be corrected for tack motion if the apparent wind relative to the course acts at sharp angles. The block operation algorithm is described by the following conditions:

$$
\varphi_{r e f}= \begin{cases}\varphi_{p r g}, & \text { if } \pm 180 \leq \beta \leq \pm 50, \\ \varphi_{p r g} \pm(50-|\beta|), & \text { if } \pm 50<\beta \leq 0,\end{cases}
$$

where $\beta$ - the angle of the apparent wind.

Operation \pm means, if «+», then the motion by the left tack (wind from the port side), if «-», then the motion by the right tack (wind from the port side). The course correction block, as follows from (3), is included under the condition of $\pm 50<\beta \leq 0$.

In Fig. 3 CC course corrector contains a circuit consisting of an integrator - int, an adder - sum1 and a comparator - comp. The purpose of these elements is to ensure the equivalence of the paths traveled when moving left and right tacks. This is necessary to keep the ship at a given program course $\varphi_{p r g}$. For this, information on the ship's instantaneous linear speed $-V_{G P}$ is fed to the integrator, which calculates the distance traveled $S$ :

$$
S=\int V_{G P S}(t) \mathrm{d} t
$$

On the summator, the calculated value of the traveled path is compared with the maximum allowed value of this $S_{\text {MAX }}$ parameter, which is set by the operator or the corresponding subprogram. If $S \geq S_{\mathrm{MAX}}$, then at the output of the comparator a bit signal $b 3$ is generated, which signals the need to change the tack. After that, the course corrector changes the set course $\varphi_{\text {ref }}$ for movement by another tack, and at the same time changes the bit signal $b 2$, which resets the speed integration result in the integrator to zero to calculate the path traveled by the new tack.

In Fig. 5 at the time 1 , the apparent wind $\beta$ changed its direction (from $-60^{\circ}$ to $-10^{\circ}$ ), then the course corrector enters the work, which changes the set program course so that the sailing installation is able to create a driving force. The ship will begin to move the right tack. After passing a certain path $S_{R}$, the correction unit will change course for the ship to move with a left tack according to $\varphi_{r e f}$ until the path $S_{L}$ is crossed. Thus, the ship will move in zigzags along the given program course $\varphi_{\text {prg }}$. When the apparent wind changes by a larger angle of $\pm 50^{\circ}$, the sails are able to work without changing the course angle and the corrector will switch to direct mode on the program course when $\varphi_{r e f}=\varphi_{p r g}$, as shown at time $t_{2}$.

The $\mathrm{RC}$ regulator is necessary to take into account the dynamics of the hull and sea waves. In addition, this regulator implements numerous course corrections, such as magnetic declination, deviations, magnetic anomalies in particular, own field, etc. A signal of a given blade angle is formed at the output of the course regulator.

The RS speed controller is designed to take into account the dynamics of the electromechanical system for moving the blade feather, to accurately establish the specified angle of rotation of the blade feather with the given dynamic characteristics ( $\dot{\alpha}=$ optimum, $\ddot{\alpha}=$ optimum). This regulator negative feedback on the angle of rotation of the blade pen. The output signal of the RS controller is the signal of the speed of the electric actuator of the steering mechanism AM.

The on-board power supply system of the USS is supposed to be powered by direct current as electric motors for driving the sail and blade, it is advisable to use a direct current drive, drives with valve or motors. However, there are no significant restrictions on the use of any type of electric motors, the main thing in this case is high efficiency and an optimal control algorithm.

The last two blocks in Fig. 4 respectively describe the dynamic properties of the blade and ship hull as solids with an optical profile in the water stream. 


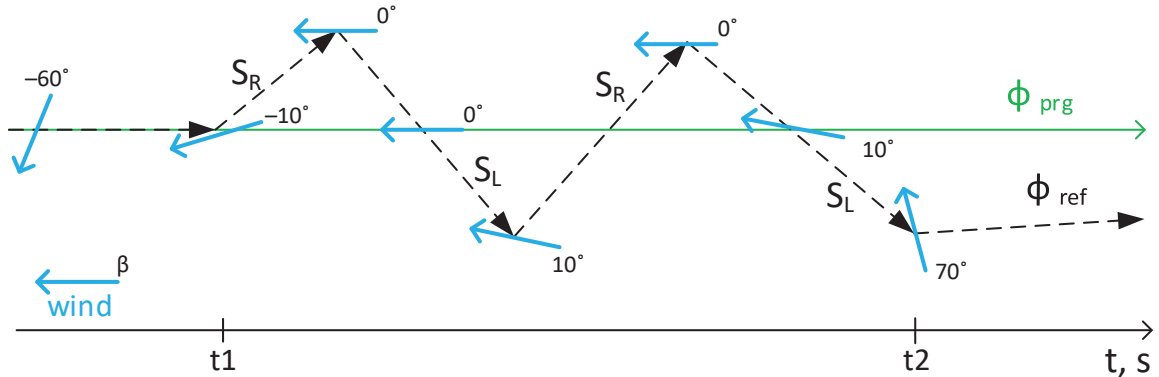

Fig. 5. Help the work of the course corrector and determine the set course angle $\varphi_{\text {ref }}$ when the ship is moving relative to the wind heading left round wind - head wind - right round wind

The following can be identified as the main problematic issues:

1. At the moments of the ship's transition from one tack to another (i. e., with $\beta=0$ ), there is an ambiguity in the choice of heading relative to the wind direction, which can be eliminated by taking into account the control history. For example, if the ship moved with the left tack, then it is obvious that for $\beta=0$ it is logical to move with the right tack.

2. At the moments when the ship is moving from one tack to another, there may be cases of speed loss and uncontrolled movement under the influence of wind in the leeward direction. To overcome this phenomenon, the USS must necessarily have a backup propulsive installation for the possibility of maneuvering.

3. The component of the aerodynamic force, rotating the ship around the longitudinal axis or heels it, affects the effective height of the sail and the change in the length of the chord of the profile in horizontal section. But it can be considered that this influence is insignificant since the design of the USS should have a very low center of gravity and/or a high center of buoyancy to ensure the highest possible stability.

4. The resultant of aerodynamic forces (except when the ship is moving at half wind and following wind) creates a torque relative to the vertical axis of the ship, since it does not coincide with it. This leads to the deviation of the ship from a given course. Overcoming this point is quite possible with the help of the ship's heading control system.

\section{Conclusions}

The study presents relatively simple control algorithms that are possible when using symmetrical aerodynamic profiles for rigid sails. Such sails will make it relatively easy to implement the modes of motion of an unmanned ship with tacks and a mode of inactivity of the sail. Also shown is the need to build a system that combines the functions of controlling the angle of attack of the wingsail and course control. In this case, the control system of the angle of attack is independent of the heading control system, and the heading control system must take into account the sailing installation mode. Overcoming the critical transition points of the ship from one tack to another is possible using an additional propulsion device.

\section{References}

1. The navy unmanned surface vehicle (USV) master plan (2007). Department of the Navy, 122.

2. Liu, Z., Zhang, Y., Yu, X., Yuan, C. (2016). Unmanned surface vehicles: An overview of developments and challenges. Annual Reviews in Control, 41, 71-93. doi: http://doi.org/10.1016/ j.arcontrol.2016.04.018

3. Pro zatverdzhennia Morskoi doktryny Ukrainy na period do 2035 roku (2009). Postanova kabinet ministriv Ukrainy No. 1307. 07.10.2009. Available at: https://zakon.rada.gov.ua/laws/main/ 1307-2009- \%D0 \%BF

4. Blincov, V. S., Magula, V. E. (1997). Proektirovanie samokhodnykh priviaznykh podvodnykh sistem. Kyiv: Naukova dumka, 140.

5. Blintsov, O. (2016). Formation of a reference model for the method of inverse dynamics in the tasks of control of underwater complexes. Eastern-European Journal of Enterprise Technologies, 4 (2 (82)), 42-50. doi: http://doi.org/10.15587/ 1729-4061.2016.74875

6. Miller, P., Judge, C., Sewell, D., Williamson, S. (2018). An Alternative Wing Sail Concept for Small Autonomous Sailing Craft. Robotic Sailing 2017, 3-17. doi: http://doi.org/10.1007/ 978-3-319-72739-4_1

7. Domínguez-Brito, A. C., Valle-Fernández, B., Cabrera-Gámez, J., Ramos-de-Miguel, A., García, J. C. (2015). A-TIRMA G2: An Oceanic Autonomous Sailboat. Robotic Sailing 2015, 3-13. doi: http://doi.org/10.1007/978-3-319-23335-2 1

8. Li, Q., Nihei, Y., Nakashima, T., Ikeda, Y. (2015). A study on the performance of cascade hard sails and sail-equipped vessels. Ocean Engineering, 98, 23-31. doi: http://doi.org/10.1016/ j.oceaneng.2015.02.005

9. Silva, M. F., Friebe, A., Malheiro, B., Guedes, P., Ferreira, P., Waller, M. (2019). Rigid wing sailboats: A state of the art survey. Ocean Engineering, 187, 106150. doi: http://doi.org/10.1016/ j.oceaneng.2019.106150

10. Atkinson, G. M., Binns, J. (2018). Analysis of drag, airflow and surface pressure characteristics of a segment rigid sail. Journal of Marine Engineering \& Technology, 17 (3), 143-152. doi: http://doi.org/10.1080/20464177.2018.1492341

11. Pope, A. (1949). The forces and moments over an NACA 0015 airfoil througli $180^{\circ}$ angle of attack, «Aerodigest», 4.

Nadtochii Victor, PhD, Department of Automation and Electrical Equipment, Kherson Branch of the Admiral Makarov National University of Shipbuilding, Ukraine, e-mail: nva074@gmail.com, ORCID: http://orcid.org/0000-0003-3869-3546

Nadtochiy Anatoly, PhD, Department of Automation and Electrical Equipment, Kherson Branch of the Admiral Makarov National University of Shipbuilding, Ukraine, e-mail:tasman.leh.85@gmail.com, ORCID: http://orcid.org/ 0000-0001-7470-3006

Bugrim Leonid, PhD, Associate Professor, Department of Heat Engineering, Kherson Branch of the Admiral Makarov National University of Shipbuilding, Ukraine, ORCID: https://orcid.org/00000001-6674-3227 